\title{
IN VITRO QUALITATIVE PHYTOCHEMICAL SCREENING, TLC-BIOAUTOGRAPHY AND SPOT SCREENING OF BISTORTA AMPLEXICAULIS (D.DON) GREENE EXTRACTS
}

\author{
Irsa Shafique, Saiqa Andleeb*, Shaukat Ali ${ }^{1}$, \\ Rozina Ghulam Mustafa and Anum Naseer \\ Microbial Biotechnology Laboratory, Department of Zoology, \\ University of Azad Jammu and Kashmir, Muzaffarabad, Pakistan13100
}

Keywords: Antibacterial assay, Antioxidant activity, Phytochemical screening, Bistorta amplexicaulis, TLC- Spot screening, TLC-Bioautography, MTT assay.

\begin{abstract}
The biological activities of Bistorta amplexicaulis (D.Don) Greene rhizome and leaves extracts were evaluated. In vitro antibacterial activity, direct bioautography, and spot screening of TLC developed bands were investigated against seven bacterial pathogens. Screening of phytochemical constituents was also done through both qualitative and thin layer chromatographic methods. DMSO extracts of rhizome indicated high sensitivity $(12.33 \pm 1.52$ and $11.33 \pm 0.57 \mathrm{~mm})$ against Escherichia coli. Whereas methanolic and acetonic extracts of rhizome indicated significant inhibition $(11.66 \pm 1.15$ and $11.33 \pm 0.57 \mathrm{~mm})$ of $S$. marcesscens. All leaf extracts revealed low sensitivity against E. coli. TLC-bioautography and spot screening methods showed the significant use of $B$. amplexicaulis as an antibacterial agent. Antioxidant activity indicated that acetone and DMSO extracts of rhizome and methanolic leaf extract have maximum scavenging potential. Among the screened phytochemicals, terpenoids, phenols, and quinones were detected in all extracts indicating the potential use of B. amplexicaulis as both antibacterial and antioxidant agents.
\end{abstract}

\section{Introduction}

Nature has blessed living creatures with medicinal plants, so there is a need to find their therapeutic properties by conducting pharmacological studies (Karimi et al. 2015). People living at high altitudes in Pakistan use plants in various ways such as medicine, firewood, timber wood, food, and fodder, etc (Hussain and Khaliq 1996). Even in the modern age, in developed countries, people still depend on plants derived medical systems because of their low price and minimum possible side effects as compared to modern synthetic drugs (Kazemipoor et al. 2012, Nasri 2013). Approximately $80 \%$ of plant diversity is found in mountain regions of Pakistan (Shinwari 2010) and Azad Jammu and Kashmir (AJ\&K) have a great diversity of medicinal plants. Reports on the uses of plants as traditional medicine by local communities of AJK are increasing day by day (Mahmood et al. 2011). In general, synthetic drugs are not only expensive but also cause serious side effects disturbing the normal physiological functioning of the body (Philomena 2011). The widespread usage of synthetic antibiotics to cure microbial infections is responsible for creating resistance in bacteria (Goossens et al. 2005). No doubt, indigenous use of plants is unlimited, but it is necessary to evaluate pharmaceutically important constituents responsible for curing infectious diseases. Phytochemical screening, antibacterial and antioxidant potential of different medicinal plants, namely Bergenia ciliata, Ajuga bracteosa, Medicago sativa, Artimesia vulgaris, Avena sativa, Cinnamomum camphora, Azardirachta indica, Emblica offcinalis, Tamarindus indica, Aloe vera, Carica papaya, Coriandrum sativum, Tritium vulgare, and Acanthella elongate were carried out by many workers (Retchkiman-Schabesy et al. 2006, Tolaymat et al. 2010, Huh and Kwon 2011, Lukman et al. 2011, Hafeez et al. 2017).

\footnotetext{
*Author for correspondence: <drsaiqa@gmail.com>. ${ }^{1}$ Department of Zoology, GC University, Lahore,
} Pakistan. 
Bistorta amplexicaulis in Polygonaceae widely known as Masloon is medicinally important and has been used to treat many diseases such as improving blood circulation, maintaining normal menstrual flow, reducing stomach pain, and treating various fractures muscle injuries, and inflammation of the mouth and tongue (Xie 2008). It is an effective herb to treat fractures in folk medicine (Liu and Tian 2007). In an experimental and clinical study of B. amplexicaulis on hemorheology, it was found that this herb is used for the treatment of atherosclerosis (Peng et al. 2003). The effects of $B$. amplexicaulis on bacteria and viruses were also carried out and positive results were obtained (Wang et al. 2006). B. amplexicaulis had a broad spectrum of antifungal activity (You et al. 2006). This plant has been of great interest to researchers. However, so far, its biological and pharmacological activities have not been investigated systematically. Thus this study aimed to evaluate antibacterial and antioxidant activities of different plant parts of $B$. amplexicaulis and also to investigate the plant parts chemically for determining bioactive agents that may be responsible for these biological activities.

\section{Materials and Methods}

Fresh rhizome and leaves of Bistorta amplexicaulis (D.Don) Greene (Syn.: Polygonum amplexicaule D.Don) were collected from Jehllum Valley (Lamnian), Muzaffarabad, Azad Jammu and Kashmir (AJ\&K), Pakistan. The collected plant species was identified by Dr. Abdul Rehman Niazi, Department of Botany, University of Punjab, Lahore, Pakistan. Collected plant parts were thoroughly washed under running tap water to remove dust and dried under shade for one to two weeks. The dried materials of both rhizome $(6.47 \mathrm{~g})$ and leaf $(0.438 \mathrm{~g})$ powder were dissolved in $50 \mathrm{ml}$ of ethanol, methanol, dimethyl sulfoxide (DMSO), diethyl ether, and acetone, and kept at room temperature $\left(25 \pm 2^{\circ} \mathrm{C}\right)$ for few days to ensure solubility.

Three Gram-positive cocci (Staphylococcus aureus, Streptococcus pyogenes, and Staphylococcus epidermidis) and four Gram-negative rod (Pseudomonas aeruginosa, Klebsiella pneumonia, Escherichia coli, and Serratia marcescens) bacterial pathogens were isolated from clinical samples (Urine, pus, and blood) and identified in Microbial Biotechnology Laboratory, the University of Azad Jammu and Kashmir, Muzaffarabad, Pakistan (Awan et al. 2013). The antibacterial activity was assessed by the agar well diffusion method (Rios et al. 1988). Nutrient agar (Oxoid: CMOO3) and nutrient broth media (Oxoid: CM1) were used for bacterial culture. Firstly, microorganisms were grown by inoculating a loop full of bacterial strain $\left(10^{-7}\right.$ colonyforming unit) in $3 \mathrm{ml}$ of nutrient broth medium for $16 \mathrm{hrs}$ and next day $25 \mathrm{ml}$ of nutrient broth medium was mixed with overnight culture and again incubated at $37^{\circ} \mathrm{C}$ on a rotary shaker for 24 hrs. The overnight culture was mixed with freshly prepared nutrient agar medium (NAM) at $45^{\circ} \mathrm{C}$ and was poured into the sterilized Petri dishes. In each plate, three wells of $5 \mathrm{~mm}$ diameter were made using $1 \mathrm{ml}$ of sterilized micropipette tip. Approximately $30 \mu \mathrm{l}$ of each crude extract was placed in each prepared wells and placed at $37^{\circ} \mathrm{C}$ for $24-48 \mathrm{hrs}$. Each solvent was also used as a negative control. The diameter of the zone of inhibition was measured after $24 \mathrm{hrs}$ in $\mathrm{mm}$ (Seeley et al. 2001). The results of the sensitivity tests were expressed as (0) for no sensitivity, * $(1-5 \mathrm{~mm})$ for low sensitivity, **(> 5-10 mm) for moderate sensitivity, and ***(> 10-25 mm) for high sensitivity.

The sensitivity of various groups of antibiotics such as aminoglycosides (Streptomycin 10 $\mu \mathrm{g} / \mathrm{ml}$ ), Kanamycin $10 \mu \mathrm{g} / \mathrm{ml}$, Penicillin's (Ampicillin $10 \mu \mathrm{g} / \mathrm{ml}$, Penicillin G $10 \mu \mathrm{g} / \mathrm{ml}$ ), Tetracyclines (Tetracycline $10 \mu \mathrm{g} / \mathrm{ml}$ ), and Fluoroquinolones (Ciprofloxacin $10 \mu \mathrm{g} / \mathrm{ml}$, Nalidixic acid $5 \mu \mathrm{g} / \mathrm{ml}$ ) and Chloramphenicol $10 \mu \mathrm{g} / \mathrm{ml}$ against all tested bacterial strains was assessed by agar disc diffusion method and used as a positive control (Bauer et al. 1996). 
The plant extracts were subjected to preliminary phytochemical screening using qualitative methods (Harborne 1998, Trease and Evans 2002). Total phenolic contents (mg/100 ml of extracts) were estimated using the Folin-Ciocalteu reagent method described by Zhou and $\mathrm{Yu}$ (2006). Estimation of total flavonoid contents of extracts was quantified by the illustrated method of Zou et al. (2004).

The presence of major phytochemicals of medicinal plants was further confirmed by Thin Layer Chromatography (TLC) using precoated silica gel 60F264 plates (Wagner and Bladt 2004). Five different screening systems, solvent system A \{methanol: acetic acid: distilled water ( $8 \mathrm{ml}: 2$ $\mathrm{ml}: 10 \mathrm{ml})$ \} solvent system B \{acetone: acetic acid: distilled water $(8 \mathrm{ml}: 2 \mathrm{ml}: 10 \mathrm{ml})$ \}, solvent system C \{ethanol: acetic acid: distilled water $(8 \mathrm{ml}: 2 \mathrm{ml}: 10 \mathrm{ml})$ \}, solvent system D \{butanol: acetone: distilled water $(10 \mathrm{ml}: 5 \mathrm{ml}: 20 \mathrm{ml})$ \}, and solvent system $\mathrm{E}$ \{Chloroform: acetone: distilled water $(8 \mathrm{ml}: 2 \mathrm{ml}: 10 \mathrm{ml})$ were used for better resolution of the components. The developed plates were observed under visible as well as UV light $(734 \mathrm{~nm})$. The retention factor $\left(\mathrm{R}_{\mathrm{f}}\right)$ value of each spot was calculated as $\mathrm{R}_{\mathrm{f}}=$ Distance moved by solvent up to band formation/ Total distance moved by the solvent. After the development of chromatograms on TLC plates, various chemical sprays were used for the detection of phytochemicals (Lacaille-Dubois 2007). The presence of different drugs was also confirmed by spraying a $96 \%$ ethanolic solution of potassium hydroxide $(\mathrm{KOH})$. After incubation of $10 \mathrm{~min}$, yellow zones indicated positive results. The antioxidant constituents were analyzed using TLC-developed plates followed by DPPH (2,2diphenyl-1-picrylhydrazyl) spray technique (Moore and Yin 2006).

Spot screening was performed using the modified protocol of Joshi et al. (2011). To measure the direct bioautography, the agar overlay technique was used with minor modifications as demonstrated by Slusarenko et al. (1998).

$\mathrm{ABTS}^{+}$or 2,2'-azino-bis (3-ethylbenzothiazoline-6-sulphonic acid) free radical scavenging activity was carried out to evaluate the antioxidant potential of extracts according to Re et al. (1999). On the other hand, DPPH [(diphenyl)-(2,4,6-trinitrophenyl) iminoazanium] free radical scavenging activity was also determined with slight modification (You et al. 2006). Each experiment was repeated in triplicate and Standard Deviation from absolute data was calculated (http://easycalculation.com/statistics/standard-deviation.php).

\section{Results and Discussion}

Antibacterial activity results revealed that ethanolic and DMSO rhizome extracts exhibited maximum inhibition of $E$. coli $(12.33 \pm 1.52 \mathrm{~mm}$ and $11.33 \pm 0.57 \mathrm{~mm})$. Similarly, maximum inhibition of $S$. marcesscens was recorded, when methanolic and acetone rhizome extracts were applied $(11.66 \pm 1.15 \mathrm{~mm}$ and $11.33 \pm 0.57 \mathrm{~mm}$ ) (Table 1). On the other hand, acetone, ethanol, and DMSO showed moderate inhibition of $S$. aureus $(8.66 \pm 0.57 \mathrm{~mm}, 8.0 \pm 1.0 \mathrm{~mm}$, and $8.6 \pm$ $1.52 \mathrm{~mm}), P$. aureginosa $(10.0 \pm 0.0 \mathrm{~mm}, 6.66 \pm 0.057 \mathrm{~mm}$, and $7.66 \pm 0.057 \mathrm{~mm})$, and $S$. epidermidis $(6.0 \pm 0.0 \mathrm{~mm}, 5.33 \pm 0.57 \mathrm{~mm}$, and $7.0 \pm 0.0 \mathrm{~mm})$. All leaf extracts did not affect the bacterial growth except $E$. coli (Table 1). TLC spot screening supports the antibacterial efficacy of all extracts against all tested pathogens. TLC-bioautography was done against $E$. coli, S. aureus, and $P$. aeruginosa, and active zones of inhibition of bacterial growth around bands (cleared area) were seen rather than purple color by using MTT (dimethylthiazol-diphenyltetrazolium bromide) compound (Fig. 1). This is consistent with the results of Yang et al. (2007), who reported that Pteroxygonum giraldii and $B$. amplexicaulis contained major chemical components such as diisobutyl phthalate, dibutyl phthalate, 2, 4-pentanedione, and 3-methyl-2,3-dihydrobenzofuran. These components could play an important role as antibacterial agents. Present work is consistent with the interpretation of previous findings of different researchers who reported the significant 
antibacterial effect of Rumex alveollatus (Sichani et al. 2013), Polygonum aviculare (Salama and Marraiki 2009), P. maritimum (El-haci et al. 2013).

Antibiogram analysis showed the inhibition of tested pathogens (Table 2). It was observed that $E$. coli was highly sensitive to ciprofloxacin, Tetracycline, and streptomycin $(17.0 \pm 1.0 \mathrm{~mm}$, $17.0 \pm 0.0 \mathrm{~mm}$, and $16.0 \pm 0.0 \mathrm{~mm})$. $S$. marcesscens was highly sensitive to ciprofloxacin, streptomycin, nalidixic acid, and chloramphenicol $(23.0 \pm 0.0 \mathrm{~mm}, 20.0 \pm 0.0 \mathrm{~mm}, 15.0 \pm 0.0 \mathrm{~mm}$, and $13.0 \pm 0.0 \mathrm{~mm}$ ), respectively. Klebsiella pneumoniae was highly sensitive to ciprofloxacin, kanamycin, and streptomycin $(21.0 \pm 0.0 \mathrm{~mm}, 12.0 \pm 0.0 \mathrm{~mm}$, and $20.0 \pm 0.0 \mathrm{~mm})$. Ciprofloxacin, chloramphenicol, and streptomycin showed a higher zone of inhibition against $S$. epidermidis $(25.0 \pm 0.0 \mathrm{~mm}, 13.0 \pm 0.0 \mathrm{~mm}$, and $16.0 \pm 0.0 \mathrm{~mm})$. Against $S$. pyogenes, the maximum zone of inhibition $(21.0 \pm 0.0 \mathrm{~mm}, 20.0 \pm 0.0 \mathrm{~mm}$, and $12.0 \pm 0.0 \mathrm{~mm})$ was shown by ciprofloxacin, nalidixic acid, and streptomycin. Similarly, $P$. aeruginosa was highly sensitive to ciprofloxacin, nalidixic acid, and streptomycin with a zone of inhibition $(21.0 \pm 0.0 \mathrm{~mm}, 15.0 \pm 0.0 \mathrm{~mm}$, and $15.0 \pm 0.0 \mathrm{~mm})$ while $S$. aureus was highly sensitive to ciprofloxacin $(20.0 \pm 0.0 \mathrm{~mm})$. Ampicillin and penicillin had the lowest inhibitory effect $(2.0 \pm 0.0 \mathrm{~mm})$. The low antibacterial activity of these antibiotics and their inability to inhibit the growth of microbes might be due to misuse and abuse of drugs (Osho and Bello 2010). It may be said that these extracts have a strong antibacterial effect compared to recommended antibiotics (ampicillin and penicillin).

Table 1. Zone of inhibition recorded against clinical bacterial pathogens by using rhizome and leaf extracts.

\begin{tabular}{|c|c|c|c|c|c|}
\hline \multirow{3}{*}{$\begin{array}{l}\text { Extracts } \rightarrow \\
\text { Pathogens } \downarrow\end{array}$} & \multicolumn{5}{|c|}{ Zone of inhibition $(\mathrm{M} \pm \mathrm{SD})$ in $\mathrm{mm}$ against pathogens } \\
\hline & \multicolumn{5}{|c|}{ Rhizome extract } \\
\hline & Methanol & Acetone & Diethyl ether & Ethanol & DMSO \\
\hline E. coli & $6.66 \pm 0.57 * *$ & $8.66 \pm 2.08 * *$ & $2.66 \pm 0.57 *$ & $12.33 \pm 1.52 * * *$ & $11.33 \pm 0.57 * * *$ \\
\hline S. marcesscens & $11.66 \pm 1.15^{* * *}$ & $11.33 \pm 0.57 * * *$ & $0.0 \pm 0.0$ & $0.0 \pm 0.0$ & $6.33 \pm 1.15^{* *}$ \\
\hline$K$. pneumoniae & $0.0 \pm 0.0$ & $0.0 \pm 0.0$ & $5.33 \pm 0.57 * *$ & $0.0 \pm 0.0$ & $5.0 \pm 0.0 *$ \\
\hline S. aureus & $2.66 \pm 1.52 *$ & $8.66 \pm 0.57 * *$ & $1.33 \pm 0.57 *$ & $8.0 \pm 1.0^{* *}$ & $8.66 \pm 1.52 * *$ \\
\hline S. pyogenes & $7.66 \pm 1.15^{* *}$ & $9.33 \pm 0.57 * *$ & $1.0 \pm 0.0 *$ & $7.0 \pm 0.0 * *$ & $6.0 \pm 0.0 *$ \\
\hline P. aeruginosa & $4.66 \pm 0.57 *$ & $6.66 \pm 0.57 * *$ & $0.0 \pm 0.0$ & $7.66 \pm 0.57 * *$ & $10.0 \pm 0.0 * *$ \\
\hline \multirow[t]{2}{*}{ S. epidermidis } & $0.0 \pm 0.0$ & $5.33 \pm 0.57 * *$ & $0.0 \pm 0.0$ & $7.0 \pm 0.0^{* *}$ & $6.0 \pm 0.0 * *$ \\
\hline & \multicolumn{5}{|c|}{ Leaf extracts } \\
\hline E. coli & $4.0 \pm 1.0 *$ & $1.66 \pm 0.57 *$ & $2.33 \pm 1.52 *$ & $2.66 \pm 0.57 *$ & $4 \pm 1.73 *$ \\
\hline S. marcesscens & $0.0 \pm 0.0$ & $0.0 \pm 0.0$ & $0.0 \pm 0.0$ & $0.0 \pm 0.0$ & $0.0 \pm 0.0$ \\
\hline$K$. pneumoniae & $0.0 \pm 0.0$ & $0.0 \pm 0.0$ & $0.0 \pm 0.0$ & $0.0 \pm 0.0$ & $0.0 \pm 0.0$ \\
\hline S. epidermidis & $0.0 \pm 0.0$ & $0.0 \pm 0.0$ & $0.0 \pm 0.0$ & $0.0 \pm 0.0$ & $0.0 \pm 0.0$ \\
\hline S. pyogenes & $0.0 \pm 0.0$ & $0.0 \pm 0.0$ & $0.0 \pm 0.0$ & $0.0 \pm 0.0$ & $0.0 \pm 0.0$ \\
\hline P. aeruginosa & $0.0 \pm 0.0$ & $0.0 \pm 0.0$ & $0.0 \pm 0.0$ & $0.0 \pm 0.0$ & $0.0 \pm 0.0$ \\
\hline S. aureus & $0.0 \pm 0.0$ & $0.0 \pm 0.0$ & $0.0 \pm 0.0$ & $0.0 \pm 0.0$ & $0.0 \pm 0.0$ \\
\hline
\end{tabular}

The phytochemical screening showed the presence of phytochemical constituents such as methanolic rhizome extract has free amino acids, tannins, alkaloids, terpenoids, quinones, steroids, flavonoids, phenols, and glycosides (Table 3). In acetone extracts, tannins, alkaloids, terpenoids, quinones, steroids, flavonoids, phenols, and glycosides. Diethyl ether rhizome extract showed the 
presence of alkaloids, terpenoids, flavonoids, quinones, steroids, phenols, and glycosides. Free amino acids, tannins, alkaloids, terpenoids, quinones, steroids, flavonoids, proteins, phenols, and glycosides were present in both ethanolic and DMSO extracts. The total flavonoid contents varied from 30.6 to $148 \mathrm{mg}$ rutin equivalent $\mathrm{mg} / \mathrm{g}$ were recorded. Maximum flavonoid contents were recorded in methanolic leaf extract $148 \mathrm{mg} / \mathrm{g}$ and the least was recorded in methanolic rhizome extract (Fig. 2). The yield per cent of total phenolics was also recorded from $3.987 \mathrm{mg} / \mathrm{g}$ to 130.92 $\mathrm{mg} / \mathrm{g}$ (Fig. 2).
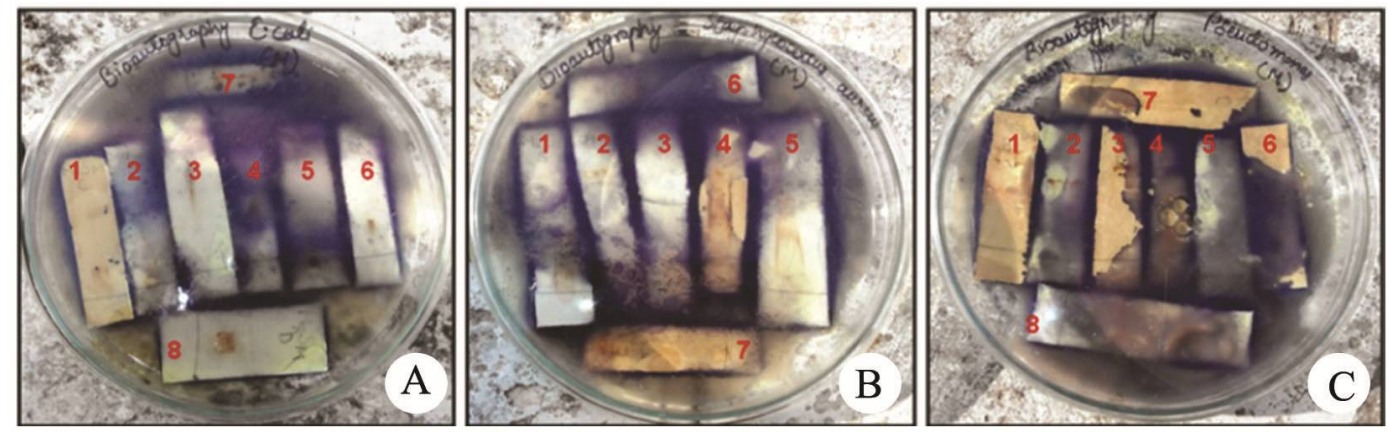

Fig. 1. TLC Bio-autography of B. amplexicaulis extracts against bacterial pathogens. (A) E. coli, (B) $S$. aureus, (C) P. aeruginosa = 1 (Methanol Ro), 2 (Ethanol Ro), 3 (DMSO Ro), 4 (DMSO L), 5 (Ethanol L), 6 (Acetone Ro), 7 (Methanol L), 8 (Acetone L), Ro (Rhizome), L (leaf).

Table 2. Zone of inhibition recorded against clinical bacterial pathogens by standard antibiotics.

\begin{tabular}{|c|c|c|c|c|c|c|c|}
\hline \multirow[b]{2}{*}{ Antibiotics } & \multicolumn{7}{|c|}{ Zone of inhibition $(\mathrm{M} \pm \mathrm{SD})$ in $\mathrm{mm}$ against pathogens } \\
\hline & $\begin{array}{c}E . \\
\text { coli }\end{array}$ & $\begin{array}{c}S . \\
\text { marcesscens }\end{array}$ & $\begin{array}{c}\text { K. } \\
\text { pneumoniae }\end{array}$ & $\begin{array}{c}S . \\
\text { epidermidis }\end{array}$ & $\begin{array}{c}S . \\
\text { pyogenes }\end{array}$ & $\begin{array}{c}P . \\
\text { aeruginosa }\end{array}$ & $\begin{array}{c}S . \\
\text { aureus }\end{array}$ \\
\hline Ciproflaxin & $17.0 \pm 1.0 * * *$ & $23 \pm 0.0 * * *$ & $21.0 \pm 0.0 * * *$ & $25.0 \pm 0.0 * * *$ & $21.0 \pm 0.0 * * *$ & $21.0 \pm 0.0 * * *$ & $20.0 \pm 0.0 * * *$ \\
\hline Nalidixic acid & $9.0 \pm 0.0^{* *}$ & $15.0 \pm 0.0 * * *$ & $10.0 \pm 0.0^{* *}$ & $2.0 \pm 0.0^{*}$ & $20.0 \pm 0.0^{* * *}$ & $15.0 \pm 0.0^{* * *}$ & $10.0 \pm 0.0 * *$ \\
\hline Tetracycline & $17.0 \pm 0.0 * * *$ & $0.0 \pm 0.0$ & $6.0 \pm 0.0 * *$ & $1.0 \pm 0.0^{*}$ & $1.0 \pm 0.0^{*}$ & $3.0 \pm 0.0^{*}$ & $7.0 \pm 0.0^{* *}$ \\
\hline Kanamycin & $9.0 \pm 0.0 * *$ & $1.0 \pm 0.0^{*}$ & $12.0 \pm 0.0 * * *$ & $1.0 \pm 0.0^{*}$ & $2.0 \pm 0.0^{*}$ & $7.0 \pm 0.0 * *$ & $9.0 \pm 0.0 * *$ \\
\hline Ampicillin & $2.0 \pm 0.0 *$ & $0.0 \pm 0.0$ & $2.0 \pm 0.0^{*}$ & $0.0 \pm 0.0$ & $0.0 \pm 0.0$ & $0.0 \pm 0.0$ & $1.0 \pm 0.0 *$ \\
\hline Penicillin G & $2.0 \pm 0.0^{*}$ & $0.0 \pm 0.0$ & $2.0 \pm 0.0^{*}$ & $0.0 \pm 0.0$ & $0.0 \pm 0.0$ & $0.0 \pm 0.0$ & $1.0 \pm 0.0 *$ \\
\hline Chloramp-henicol & $7.0 \pm 0.0 * *$ & $13.0 \pm 0.0 * * *$ & $9.0 \pm 0.0 * *$ & $13.0 \pm 0.0 * * *$ & $3.0 \pm 0.0^{*}$ & $6.0 \pm 0.0 * *$ & $6.0 \pm 0.0^{* *}$ \\
\hline Streptomycin & $16.0 \pm 0.0 * * *$ & $20.0 \pm 0.0 * * *$ & $20.0 \pm 0.0 * * *$ & $16.0 \pm 0.0^{* * *}$ & $12.0 \pm 0.0 * * *$ & $15.0 \pm 0.0^{* * *}$ & $10.0 \pm 0.0 * *$ \\
\hline
\end{tabular}

According to preliminary screening, different secondary metabolites were present in plants in variable amounts. TLC was performed for further confirmation of these bioactive constituents of B. amplexicaulis (Fig. 3). Hawryl and Waksmundzka (2011) reported the separation of different phytochemical constituents via TLC from genus Polygonum. Thin Layer Chromatography (TLC) performed on the extracts of $B$. amplexicaulis indicated the separation of the chemical constituents in the form of bands. In solvent system A (methanol: acetic acid: distilled water) all rhizome extracts showed $R_{f}$ values as $0.5,0.357,0.843,0.733$, and 0.866 respectively (brownish color ranges from light brown to dark), indicating the presence of various constituents like amines, 

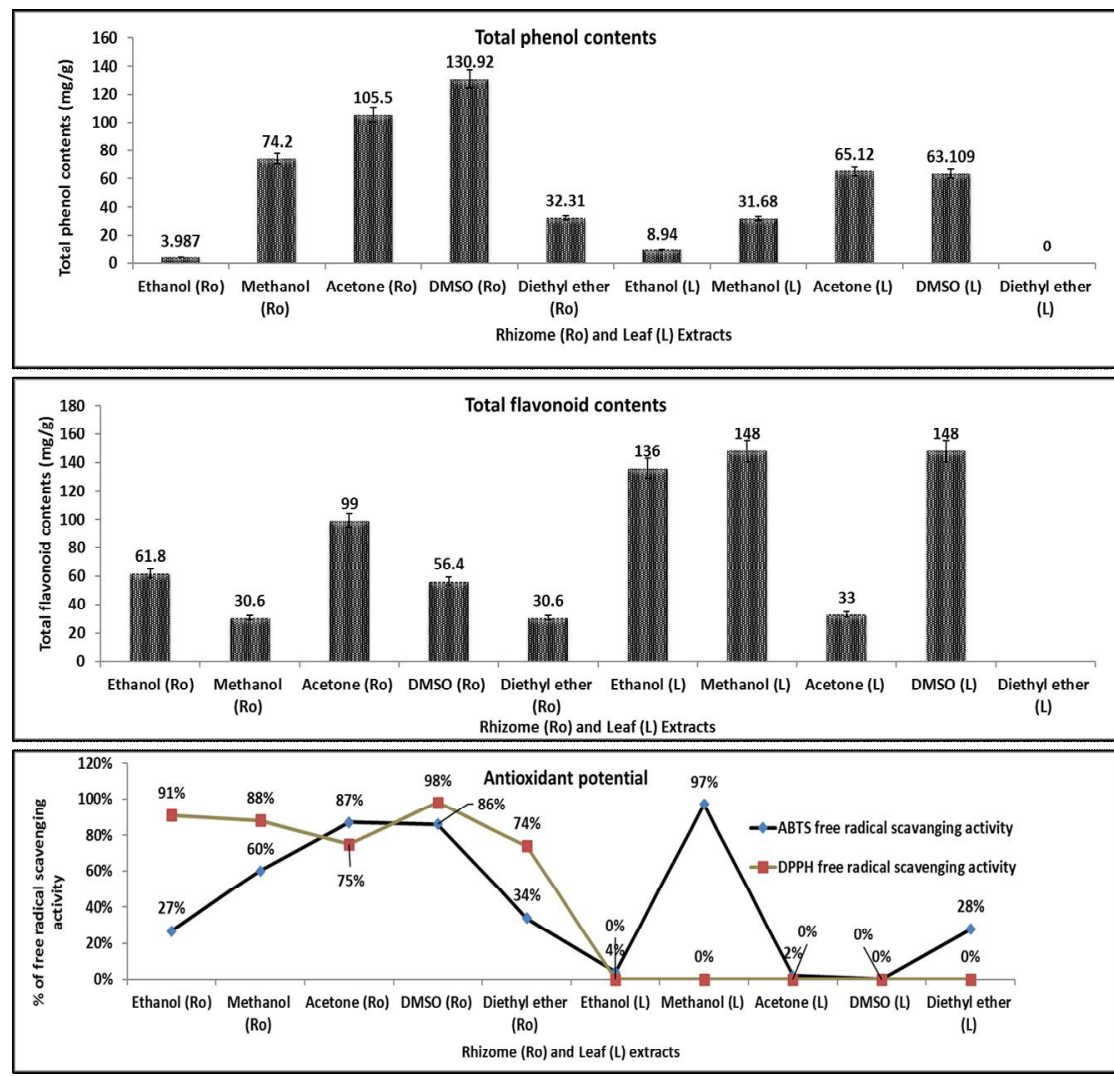

Fig. 2. Total phenolic and flavonoid contents, and antioxidant potential of B. amplexicaulis extracts.

Table 3. Phytochemical screening of B. amplexicaulis extracts.

\begin{tabular}{|c|c|c|c|c|c|c|c|c|c|c|}
\hline \multirow[b]{2}{*}{$\begin{array}{l}\text { Phytochemical } \\
\text { constituents } \downarrow \\
\text { Extracts } \rightarrow\end{array}$} & \multicolumn{5}{|c|}{ Rhizome } & \multicolumn{5}{|c|}{ Leaf } \\
\hline & $\begin{array}{c}\text { Metha- } \\
\text { nol }\end{array}$ & Acetone & $\begin{array}{c}\text { Diethyl } \\
\text { ether }\end{array}$ & Ethanol & DMSO & $\begin{array}{c}\text { Metha- } \\
\text { nol }\end{array}$ & Acetone & $\begin{array}{c}\text { Diethyl } \\
\text { ether }\end{array}$ & $\begin{array}{c}\text { Etha- } \\
\text { nol }\end{array}$ & DMSO \\
\hline Free amino acids & + & - & - & + & + & - & - & - & - & - \\
\hline Tannins & + & + & - & + & + & - & - & - & - & + \\
\hline Alkaloids & + & + & + & + & + & + & + & - & + & + \\
\hline Saponins & - & - & - & - & - & - & - & - & - & - \\
\hline Terpenoids & + & + & + & + & + & + & + & + & + & + \\
\hline Carbohydrates & - & - & - & - & - & - & - & - & - & - \\
\hline Quinones & + & + & + & + & + & + & + & + & + & + \\
\hline Steroids & + & + & + & + & + & - & + & + & - & - \\
\hline Flavonoids & + & + & + & + & + & + & + & + & + & + \\
\hline Phenols & + & + & + & + & + & + & + & + & + & + \\
\hline Glycosides & + & + & + & + & + & - & + & + & - & + \\
\hline Proteins & - & - & - & + & + & - & - & - & - & + \\
\hline
\end{tabular}

(+) indicates presence; (-) indicates absence. 


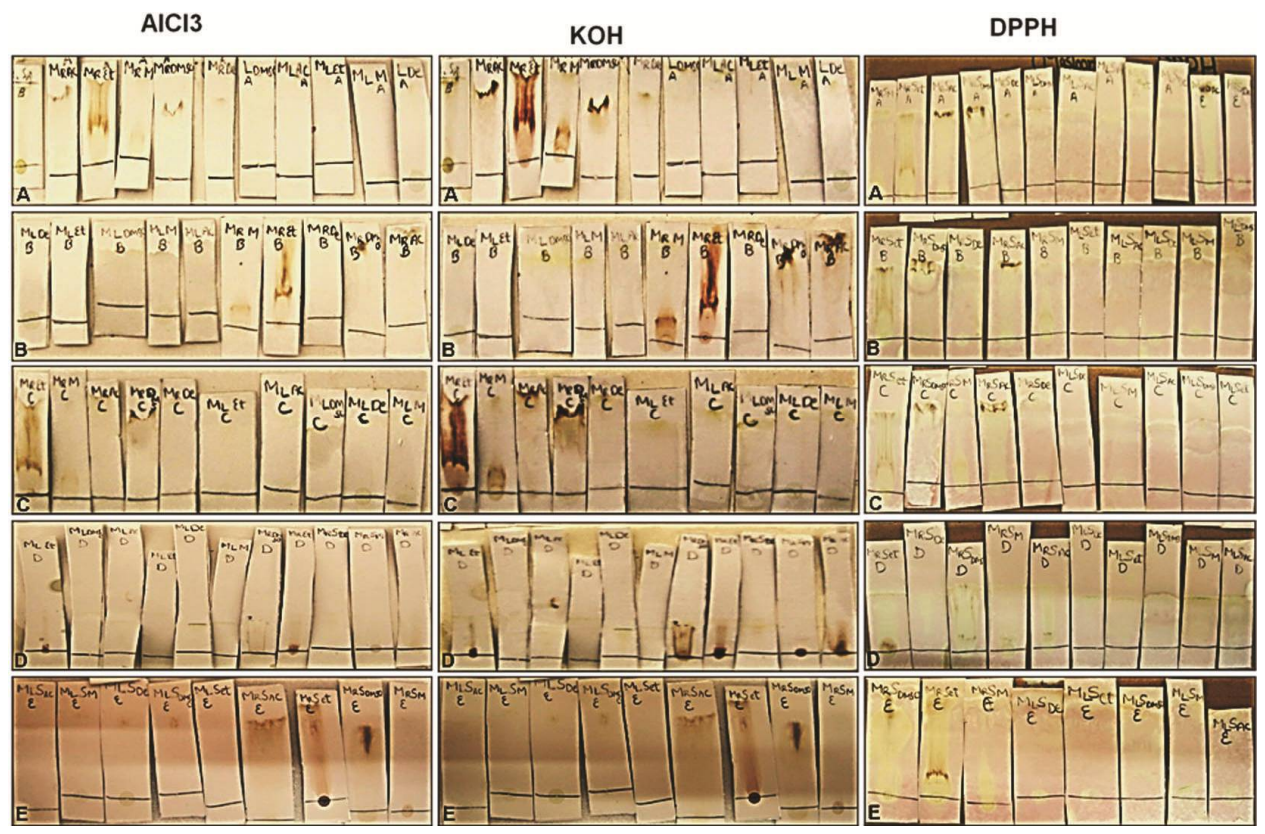

Fig. 3. Thin layer chromatography of B. amplexicaulis using various chemicals via spray technique.

terpenoids, phenols, steroids, and flavonoids. But all leaf extracts showed no resolution of components. Similarly, in solvent system B (acetone: acetic acid: distilled water) all polar solvents showed $\mathrm{R}_{\mathrm{f}}$ values of $0.303,0.2,0.914$, and 0.94 with brown colored bands. In solvent system $\mathrm{C}$ (ethanol: acetic acid: distilled water) only ethanolic and methanolic extracts showed $R_{f}$ values of 0.285 and 0.228 , respectively with brown colored bands. In solvent system D (butanol: acetone: distilled water) only ethanol, acetone, and DMSO rhizome extracts showed resolution of the components and $R_{f}$ values for these extracts were recorded as 0.15, 0.285, and 0.6388, respectively. In this solvent system, the leaf extract of diethyl ether showed a light green-colored band with $R_{f}$ value of 0.66. Similarly, for solvent system E (Chloroform: acetic acid: distilled water) only ethanol, acetone, and DMSO rhizome extracts showed $\mathrm{R}_{\mathrm{f}}$ values as $1.175,0.833$, and 0.844 , respectively with brown colored bands which revealed the presence of different bioactive components. The appearance of light brown color revealed positive results for the presence of flavonoids on TLC-developed plates when sprayed with methanolic/ethanolic solution of aluminium chloride. Similarly, after spraying $96 \%$ ethanolic solution of potassium hydroxide $(\mathrm{KOH})$ on TLC-developed plates, the formation of yellow zones indicated the presence of different drugs (Fig. 3). In general, It may be said that B. amplexicaulis could be used against various diseases such as atherosclerosis, bacterial infections, cardiovascular diseases, improving blood circulation, and maintaining normal menstrual flow (Xie 2008).

Results revealed that $B$. amplexicaulis rhizome extracts possessed phytochemical constituents such as phenols, alkaloids, terpenoids, flavonoids, quinones, steroids, and glycosides that play a vital role in the prevention of infectious diseases. The present findings are in agreement with the previous report that glycosides, steroids, flavonoids, phenols act as antimicrobial agents (Mann et al. 2008, Gursoy and Tape 2009, Maneemegalai and Naveen 2010, Patil et al. 2010).

It was observed that acetone and DMSO rhizome extract of $B$. amplexicaulis showed stronger $\mathrm{ABTS}^{+}$scavenging potential (87 and $86 \%$ ). The maximum scavenging activity of DMSO and 
ethanol rhizome extracts was recorded as 98 and 91\% through the DPPH method. All leaf extracts showed negative results indicating the absence of DPPH scavenging ability (Fig. 2). DPPH sprayon TLC-developed plates, yellowish spots were detected with the purple background which indicated the presence of antioxidant components (Fig. 3). Previously it was reported that extracts of roots from $P$. capsidatum and $P$. muliflorum had strong $\mathrm{DPPH}^{+} / \mathrm{ABTS}^{+} / \mathrm{OH}^{-}$radical scavenging activities (Cai et al. 2004). These results are consistent with the present findings. Thus, it may be suggested that $B$. amplexicaulis rhizome extracts could be a good source of antioxidants, and can also be used as antioxidant supplementation.

Considering the results of biological assays, it may be concluded that most of the tested fractions appeared as an important source for the discovery of new antimicrobial drugs having the massive remedial potential to cure many infectious diseases with no side effects. The extracts of this medicinal plant can be effectively used as potential antimicrobial and antioxidant agents to overcome the problem of bacterial infections.

\section{References}

Awan UA, Andleeb S, Kiyani A, Zafar A, Shafique I, Riaz N, Azhar MT, Uddin H. 2013. Antimicrobial screening of traditional herbal plants and standard antibiotics against some human bacterial pathogens. Pak. J. Pharm. Sci. 26: 1109-1116.

Bauer AW, Kirby WMM, Sherris JC and Turck M 1996. Antibiotic susceptibility testing by standardized single disk method. Am. J. Clin. Pathol. 36: 493-6.

Cai YZ, Luo Q, Sun M and Corke H 2004. Antioxidant activity and phenolic compounds of 112 traditional Chinese medicinal plants associated with anticancer. Life Sci. 74: 2157-84.

El-haci IAF, Bekkara A, Mazari W, Hassani F and Didi MA 2013. Screening of biological activities of Polygonum maritimum L. from Algerian coast. Asian Pac. J. Trop. Biomed. 3: 611-616.

Goossens H, Ferech M, Stichele VR and Elseviers M 2005. Outpatient antibiotic use in Europe and association with resistance: A cross-national database study. Lancet 365: 579-587.

Gursoy N, Tepe B. 2009. Determination of the antimicrobial and antioxidative properties and total phenolics of two "endemic" Lamiaceae species from Turkey: Ballota rotundifolia L. and Teucrium chamaedrys C. Koch. Plant Foods Hum. Nutr. 64(2): 135-140.

Hafeez K, Andleeb S, Ghous T, Mustafa RG, Naseer A, Shafique I, Akhter K. 2017. Phytochemical screening, alpha-glucosidase inhibition, antibacterial and antioxidant potential of Ajuga bracteosa Extracts. Current Pharma. Biotechnol. 18(4): 336-342.

Harborne JB 1998. Phytochemical Methods: A Guide to Modern Techniques of Plant Analysis, 3rd Ed., London: Chapman and Hall. 40-137.

Hawryl MA and Waksmundzka HM 2011. Two-dimensional thin-layer chromatography of selected Polygonum sp. extracts on polar-bonded stationary phases. J. Chromatogr. A. 1218: 2812-2819.

Huh AJ, Kwon YJ. 2011. Nanoantibiotics: a new paradigm for treating infectious diseases using nanomaterials in the antibiotics resistant era. J. Control Release. 156(2): 128-145.

Hussain F and Khaliq A 1996. Ethnobotanical studies on some plants of Dabargai Hills. Swat. Proceedings of first training workshop on Ethnobotany and its application to conservation. NARC, Islamabad. 207-215.

Joshi B, Sah GB, Basnet BB, Bhatt MR, Sharma D, Subedi K, Panday J and Malla R 2011. Phytochemical extraction and antimicrobial properties of different medicinal plants: Ocimum sanctum (Tulsi), Eugenia caryophyllata (Clove), Achyranthes bidentata (Datiwan) and Azadirachta indica (Neem). J. Microbiol. Antimicrob. 3: 1-7.

Karimi A, Majlesi M, Rafieian-Kopaei M. 2015. Herbal versus synthetic drugs; beliefs and facts. J. Nephropharmacol. 4(1): 27-30.

Kazemipoor M, Radzi CW, Cordell GA, Yaze I. 2012. Safety, efficacy and metabolism of traditional medicinal plants in the management of obesity: a review. Int. J. Chem. Eng. Appl. 3(4): 288-92. 
Lacaille-dubois MA 2007. Bioactive Saponins from plants: Recent Development in Yaniv Z, Bacherach U. editors. Handbook of Medicinal plants: India, Harworth Press. 5: 1-7.

Liu CF and Tian GH 2007. Study on volatile components and antimicrobial activity of the essential oil from Polygonum amplexicaule. Nat. Prod. Res. Dev. 3: 1261-1263.

Lukman AI, Gong B, Marjo CE, Roessner U, Harris AT. 2011. Facile synthesis, stabilization, and antibacterial performance of discrete Ag nanoparticles using Medicago sativa seed exudates. J. Colloid. Interface Sci. 353: 433-444.

Mahmood ARA, Qureshi A, Mahmood Y, Sangi H, Shaheen I and Nawaz Z 2011. Ethnobotanical survey of common medicinal plants used by people of district Mirpur, AJK, Pakistan. J. Med. Plants Res. 5: 44934498.

Maneemegalai S, Naveen T. 2010. Evaluation of antibacterial activity of flower extracts of Cassia auriculata. Ethnobotanical Leaflets. 14: 8-20.

Mann A, Yahaya Y, Banso A, John F. 2008. Phytochemical and antimicrobial activity of Terminalia avicennioides extracts against some bacteria pathogens associated with patients suffering from complicated respiratory tract diseases. J. Med. Plants Res. 2(5): 094-097.

Moore J and Yin JY 2006. Novet fluorometric assay for HOSC Estimation. J. Agr. Food Chem. 54: 617-626.

Nasri H. 2013. Cisplatin therapy and the problem of gender-related nephrotoxicity. J. Nephropharmacol. 2(2): $13-4$.

Osho A and Bello OO 2010. Antimicrobial effect of honey produced by on some common human pathogens Apis mellifera. Asian J. Ex. Biol. Sci. 1: 875-880.

Patil UH. Gaikwad DK, Chavan PD. 2010. Antibacterial activity of stem bark of Boswellia serrata (Roxb.). Bioinfolet. 7(2): 137-139.

Peng ZF, Strack D, Baumert A, Subramaniam R, Goh NK, Chia TF, Tan SN, Chia LS 2003. Antioxidant flavonoids from leaves of Polygonum hydropiper L. Phytochem. 62: 219-228.

Philomena G. 2011. Concerns regarding the safety and toxicity of medicinal plants - An overview. J. Appl. Pharmaceut. Sci. 1(6): 40-44.

Re RN, Pellegrini A, Proteggente A, Pannala MY and Rice-Evans C 1999. Antioxidant activity applying an improved ABTS radical cation decolorization assay. Free Radic. Biol. Med. 26: 1231-1237.

Retchkiman-Schabes PS, Canizal G, Becerra-Herrera R, Zorrilla C, Liu HB, Ascencio J. 2006. Biosynthesis and characterization of Ti/Ni bimetallic nanoparticles. Opt. Mater. 29(1): 95-98.

Rios JL, Recio MC and Villar, A 1988. Screening methods for natural products with antimicrobial activity: A review of literature. J. Ethnopharmacol. 23: 127-149.

Salama HMH and Marraiki N 2009. Antimicrobial activity and phytochemical analysis of Polygonum aviculare L. (Polygonaceae), Naturally Growing in Egypt. Aus. J. Basic App. Sci. 3: 2008-2015.

Seeley HW, Vandemark PJ and Lee JJ 2001. Microbes in action: A Laboratory manual of microbiology. $4^{\text {th }}$ Edition. W.H. Freeman and Co New York. 57-130.

Shinwari ZK 2010. Medicinal plants research in Pakistan. J. Med. Plant Res. 4: 161-176.

Sichani MM, Sadeghzadeh P and Madani M 2013. Evaluation of antibacterial activity of extract of Rumex alveollatus leaf against Staphylococcus aureus and Pseudomonas aeruginosa. Zahedan J. Res. Med. Sci. 15: 58-61.

Slusarenko AJ, Longland AC, and Whitehead IM 1998. Convenient, sensitive and rapid assay for antibacterial activity of phytoalexins. Bot. Helv. 99(2): 203-207.

Tolaymat TM, El Badawy AM, Enaidy A, Scheckel KG, Luxton TP, Suidan M. 2010. An evidence-based environmental perspective of manufactured silver nanoparticle in syntheses and applications: A systematic review and critical appraisal of peer reviewed scientific papers. Sci. Total Environ. 408: 9991006.

Trease GE and Evans WC 2002. Pharmacognasy, $15^{\text {th }}$ Ed. Saunders Publishers London. 221-393.

Wagner H, Bladt S 2004. Plant drug analysis-A thin layer chromatography atlas. $2^{\text {nd }}$.ed. New Dehli, India. Thompson Press Ltd. 14-247. 
Wang KJ, Zhang YJ and Yang CR 2006. Recent advance on the chemistry and bioactivity of genus Polygonum. Nat. Prod. Res. Dev. 18: 151-164.

Xie ZW 2008. National herbal compendium. The people's health publication House, Beijing. 316-322.

Yang ZJ, Li BL, Tian XH and Liang B 2007. Chemical constituents of the essential oils of Pteroxygonum giraldii and Polygonum amplexicaule. Acta Bot. Boreal-occident Sin. 6: 1261-1264.

You WC, Brown LM, Zhang L, Li JY, Jin ML and Chang YS 2006. Randomized double-blind factorial trial of three treatments to reduce the prevalence of precancerous gastric lesions. J. Nat. Cancer Inst. 98: 974983.

Zou K and Yu L 2006. Total phenolic contents and antioxidant properties of commonly consumed vegetables grown in colorada. LWT- Food Sci. Technol. 39: 1155-1162.

Zou Y, Lu Y and Wei D 2004. Antioxidant activity of a flavonoid rich extract of Hypericum perforatum L. in vitro J. Agri. Food Chem. 52: 5032-5039.

(Manuscript received on 28 August, 2019; revised on 2 March, 2021) 